\title{
Feeding preferences for juvenile and adult algae depend on algal stage and herbivore species
}

\author{
Kathryn L. Van Alstyne*, Janette M. Ehlig, Shauna L. Whitman
}

Department of Zoology, Oregon State University, Corvallis, Oregon 97331, USA

\begin{abstract}
Juvenile marine organisms are physically and chemically different from adults. Consequently, the ecology of juveniles, particularly their interactions with other organisms, may change as they age. Yet, they are often considered to function as 'miniature adults'. To explore how ecological interactions change as juvenile seaweeds mature, we investigated among-species food preferences of 4 species of grazers for 8 species of common intertidal and subtidal macroalgae in laboratory multiplechoice feeding-preference experiments. Grazers were offered either juvenile tissues or adult tissues of 8 species of macroalgae. Food preferences of grazers among both juvenile and adult brown algae differed among herbivore species. Within herbivore species, the relative grazing rates on juveniles of a given species were not significantly correlated with grazing rates on adult tissues of that species. Thus, food preferences of herbivores among species of macroalgae are dependent upon the age of the algal tissue and the species of herbivore being considered. Stage-specific differences in preferences between juveniles and adults are likely a result of chemical and morphological changes occurring during algal development. Further work is needed to characterize these changes and further determine their impacts on the ecological characteristics of juvenile marine macroalgae.
\end{abstract}

KEY WORDS: Brown algae - Development · Food preferences - Herbivory · Juveniles

\section{INTRODUCTION}

Herbivory is important in determining the final structure of many marine benthic communities (Lubchenco 1978, 1983, Lubchenco \& Menge 1978, Duggins 1980, Hay 1981, 1985, Lubchenco \& Gaines 1981, Hawkins \& Hartnoll 1983, Steneck 1983, 1986, 1988, Duggins \& Dethier 1985, Carpenter 1986, Lewis 1986, Schiel \& Foster 1986, Witman 1987). Grazers often exert their influence on community dynamics by consuming the sporeling or juvenile stages of algae (Lubchenco 1978, 1983, Robles \& Cubit 1981, Dayton 1985, Dean et al. 1989, Asano et al. 1990, Paine 1992). Macroalgae that survive through the early sporeling stages of their life-history tend to persist because they become too large to be removed by most herbivores and 'escape in size' (Lubchenco \& Gaines 1981).

\footnotetext{
- Present Address: Shannon Point Marine Center, 1900 Shannon Point Road, Anacortes, Washington 98221, USA.

E-mail:kathyva@cc.wwu.edu
}

Herbivore food preferences, as demonstrated in laboratory feeding experiments, are helpful in predicting which species are most likely to be consumed in the field and consequently which species are likely to persist in the community. However, most food preference studies are conducted with adult algae, which may be physically and chemically different from juveniles. Juvenile stages of algae are thinner and puncture more easily than adults (K. Van Alstyne et al. unpubl.). Phlorotannins, or polyphenolic compounds, which are thought to function as chemical defenses towards some species of herbivores (Geiselman \& McConnell 1981. Steinberg 1984, 1985, 1988, Ragan \& Glombitza 1986, Van Alstyne \& Paul 1990, Targett \& Arnold 1998), occur in different concentrations in juveniles and adults (Denton et al. 1990, Van Alstyne et al. unpubl.). Therefore, it is probable that food preferences of herbivores among species of adult macroalgae may differ from herbivore preferences for juveniles.

In this study, we examine food preferences of $4 \mathrm{com}$ mon intertidal and subtidal invertebrate herbivores for 
juvenile and adult stages of some common species of kelps and fucoid brown algae. We conducted laboratory multiple-choice feeding-preference assays to determine the relative preferences of herbivores among species of seaweeds. We then compared preferences for juveniles versus adults to determine if the preferences were stage-specific.

\section{MATERIALS AND METHODS}

Collection sites. Purple sea urchins (Strongylocentrotus purpuratus), snails (Lacuna porrecta and Tegula funebralis), and isopods (Idotea wosnesenskii) were collected from low to mid intertidal pools at Boiler Bay, OR, USA, $\sim 5 \mathrm{~km}$ north of the town of Depoe Bay, OR. All animals were kept in flow-through seawater tables at the Hatfield Marine Science Center (HMSC) in Newport, OR, and fed a mixture of macrophytes that included species used in feeding experiments. Juvenile and adult individuals of 6 species of kelps, Alaria marginata, Costaria costata, Egregia menziesii, Hedophyllum sessile, Lessoniopsis littoralis, and Nereocystis luetkeana, and 2 species of fucoid brown algae, Fucus gardneri and Fucus spiralis, were also collected from Boiler Bay. Within 2 to $3 \mathrm{~h}$ of collection, algae were transported on ice to HMSC where they were immediately used in feeding-preference experiments. Juveniles were the smallest recognizable individuals we could find for each species; most were 2 to $10 \mathrm{~cm}$ long. Adult algae were the same size as reproductive individuals of a given species, although individuals used in these experiments were not always in reproductive condition.

Feeding preference assays. In each experiment, consumers (either Strongylocentrotus purpuratus, Tegula funebralis, Idotea wosnesenskii or Lacuna porrecta) were offered similar sized pieces of juvenile and adult algae. The pieces given to urchins had a mass of $\sim 0.5 \mathrm{~g} ;$ T. funebralis were given $\sim 0.25 \mathrm{~g}$ pieces and $L$. porrecta and $I$. wosnesenskii were given pieces of $\sim 0.15 \mathrm{~g}$. Experiments with all herbivores except $L$. por recta were conducted in $5 \mathrm{~cm}$ diameter plastic Rubbermaid $^{\text {TM }}$ containers that had been modified by removing $3 \mathrm{~cm}$ diameter pieces from the bottoms and lids and replacing them with $1 \mathrm{~mm}$ mesh fiberglass screening to allow water flow through the containers. Experiments with L. porrecta were performed in $40 \mathrm{~mm}$ diameter plastic Petri dishes that had been modified by cutting $25 \mathrm{~mm}$ diameter holes in both parts of the dish and covering them with $1 \mathrm{~mm}$ mesh fiberglass screening. All experiments took place in outdoor flowthrough seawater tables at HMSC. Animals were starved for 2 to $4 \mathrm{~d}$ prior to conducting feeding-preference experiments so they would consume the algae before it started deteriorating. Cronin \& Hay (1996) found that starving the sea urchins Arbacia punctulata caused them to be less selective when offered choices of artificial diets with and without secondary metabolites in them; it is not known whether all herbivores respond to starvation in this way or if starvation affects preferences for intact algae.

Multiple-choice feeding-preference experiments were conducted to assess preferences among species of macroalgae. In each experiment, herbivores were simultaneously offered choices of 8 foods, either pieces of adult Alaria marginata, Costaria costata, Egregia menziesii, Fucus gardneri, F. spiralis, Hedophyllum sessile, Lessoniopsis littoralis, and Nereocystis luetkeana, or pieces of juvenile plants of the same species $(\mathrm{N}=5$ to 11 ). An equal number of control arenas in each experiment contained algae without herbivores and were used to assess autogenic changes in the algae that occurred during the course of the experiments.

Algal pieces were blotted dry and weighed prior to the start of the experiments. Containers were checked periodically and herbivores were removed when at least half the algae in the container had been consumed. At the conclusion of the experiment, experimental and control algae were again blotted dry and reweighed to determine mass changes. Data from experimental replicates in which less than $25 \%$ or greater than $75 \%$ of the algae was consumed were discarded.

A Yao's $R$ test was used to determine whether food preferences among species differed significantly in each experiment. Yao's $R$ is a multivariate method that is appropriate for data from multiple-choice feedingpreference experiments in which consumption rates are not independent within arenas (Manly 1993).

For each of the 8 algal species, an overall mass change was calculated separately for juveniles and adults by subtracting the mean mass changes (final masses minus initial masses) in the control arenas from the mean mass changes in the experimental arenas. Correlation analyses were conducted between the overall mass change of adult tissues versus the overall mass change of juvenile tissues to determine if amongspecies preferences for juveniles and adults were correlated within each herbivore species.

\section{RESULTS}

Herbivores exhibited significant preferences ( $\alpha=$ 0.05 in Yao's $R$ tests) among algal species in most of the feeding experiments (Figs. 1 to 4 ). The preferences differed among the species of herbivores and between juveniles and adult algae within species of herbivores 


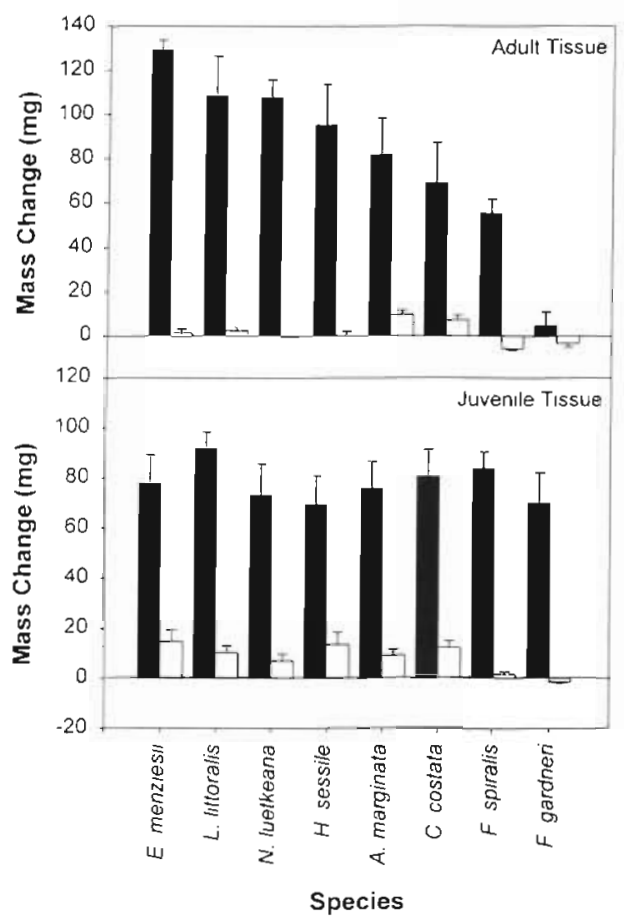

Fig. 1. Consumption rates of juvenile $(\mathrm{N}=11)$ and adult $(\mathrm{N}=$ 10) brown algal tissues by Strongylocentrotus purpuratus. Urchins were offered tissues from all 8 species simultaneously. Black bars represent mean mass changes of algal tissues $\pm 1 \mathrm{SE}$ in experimental arenas with herbivores. White bars represent mean mass changes of algal tissues $\pm 1 \mathrm{SE}$ in control arenas without herbivores. Consumption rates of adult tissues, but not juvenile tissues, differed significantly among species (adults: $\mathrm{p}=0.0016$ from Yao's $R$ test $_{i}$ juveniles: $\mathrm{p}=$ 0.8244 from Yao's $R$ test)

In experiments with adult tissues, sea urchins consumed larger amounts of kelp than fucoid brown algae (Fig. 1). However, no significant preference ( $p>0.05$ in Yao's $R$ tests) was displayed by the urchins among species of juveniles. Tegula funebralis and Lacuna porrecta also preferred adult kelps to adult fucoid brown algae (Figs. 2 \& 3). When offered juvenile tissues, they showed significant preferences among species ( $T$. funebralis: $\mathrm{p}=0.001$, L. porrecta: $\mathrm{p}<0.001$ in Yao's $R$ tests), but these preferences were different than preferences for adults. In experiments with $T$. funebralis, this was especially notable for Lessoniopsis littoralis, which was preferred as adults, but not as juveniles, and Alaria marginata which was a low preference food as an adult but a high preference food as a juvenile (Fig. 2). Similarly, Costaria costata juveniles were highly preferred by L. porrecta, but adults were only an intermediate preference food (Fig. 3). Food preferences among adult tissues by Idotea wosnesenskii were different from preferences of other herbivores (Fig. 4). I. wosnesenskii exhibited the highest preference for both adult and juvenile Alaria marginata and

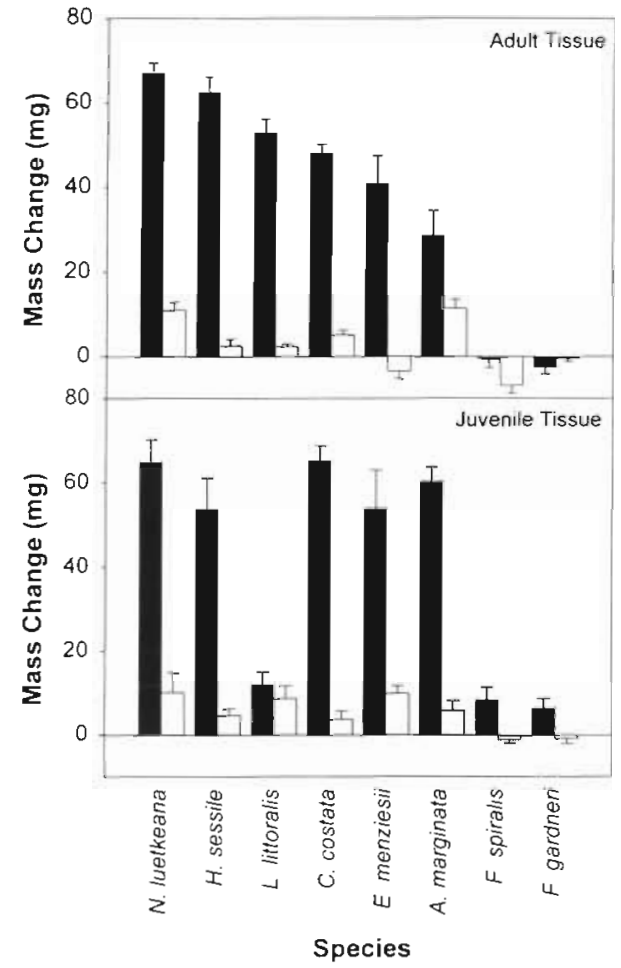

Fig. 2. Consumption rates of juvenile $(N=8)$ and adult $(N=5)$ brown algal tissues by Tegula funebralis. Symbols as in Fig. 1. Consumption rates of adult and juvenile tissues differed significantly among species (adults: $p=0.0001$ from Yao's $R$ test; juveniles: $p<0.001$ from Yao's $R$ test)

intermediate preferences for adult Fucus spiralis, a low preference food for the other 3 herbivores (Figs. 1 to 3 ). Preferences for juveniles tracked preferences for adults more closely in the $I$. wosnesenskii preference experiments than for the other herbivores (Fig. 4).

There were no significant correlations between preferences for adult and juvenile tissues (Fig. 5; Strongylocentrotus purpuratus: Pearson correlation coefficient $=0.224, p>0.05$, Tegula funebralis: Pearson correlation coefficient $=0.494, p>0.05$, Lacuna porrecta: Pearson correlation coefficient $=0.167, \mathrm{p}>0.05$, Idotea wosnesenskij: Pearson correlation coefficient $=$ $0.625, \mathrm{p}>0.05)$.

\section{DISCUSSION}

Changes in morphology, chemistry, behavior, and mortality accompany the transition from juvenile to adult stages in marine organisms (Bernard 1967. Werner \& Gilliam 1984, Hooker \& Morse 1985, Zann et al. 1987, Rowley 1990, Keesing \& Halford 1992, Gosselin \& Chia 1994, 1995a,b, 1996, Lindquist \& Hay 1996, Gosselin 1997). In a survey of survival in recently 


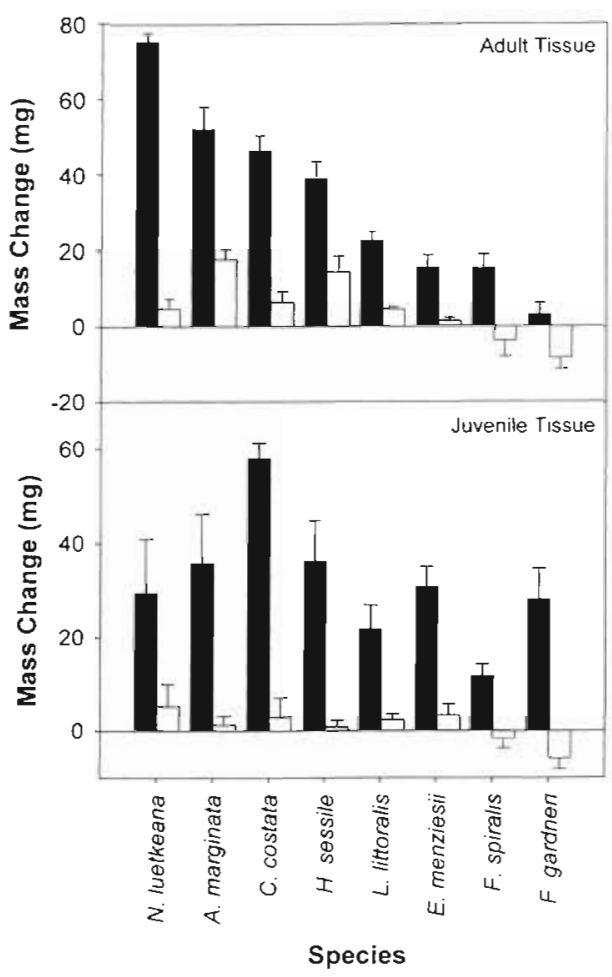

Fig. 3. Consumption rates of juvenile $(N=7)$ and adult $(N=9)$ brown algal tissues by Lacuna porrecta. Symbols as in Fig. 1. Consumption rates of adult and juvenile tissues differed significantly among species (adults: $p=0.0118$ from Yao's $R$ test; juveniles: $\mathrm{p}=0.0333$ from Yao's $R$ test)

settled marine invertebrates, Gosselin \& Quan (1997) found that mortality rates of juveniles were generally highest the first day after settlement and strongly declined thereafter. Changes in mortality during development were often a result of decreases in the susceptibility of juveniles to predation and desiccation as they aged.

Much less is known about differences between the physical properties, chemical properties, and ecology of juvenile and adult macroalgae. Juvenile survival rates of macroalgae are thought to be affected by temperature and desiccation stresses (Brawley \& Johnson 1991), herbivory (Lubchenco 1983, Brawley \& Johnson 1991. Worm \& Chapman 1998), freezing (Bird \& McLachlan 1974), competition with other algal species (Reed 1990, Worm \& Chapman, 1998), and wave action (Vadas et al. 1990). However, little data are available comparing the effects of these stresses on survival at different life-history stages.

Our study showed that a change in food preferences by herbivores occurs as plants age; a species that is a preferred food as a juvenile is not necessarily a preferred food as an adult. Juvenile algae differ from adults in a number of physical and chemical properties

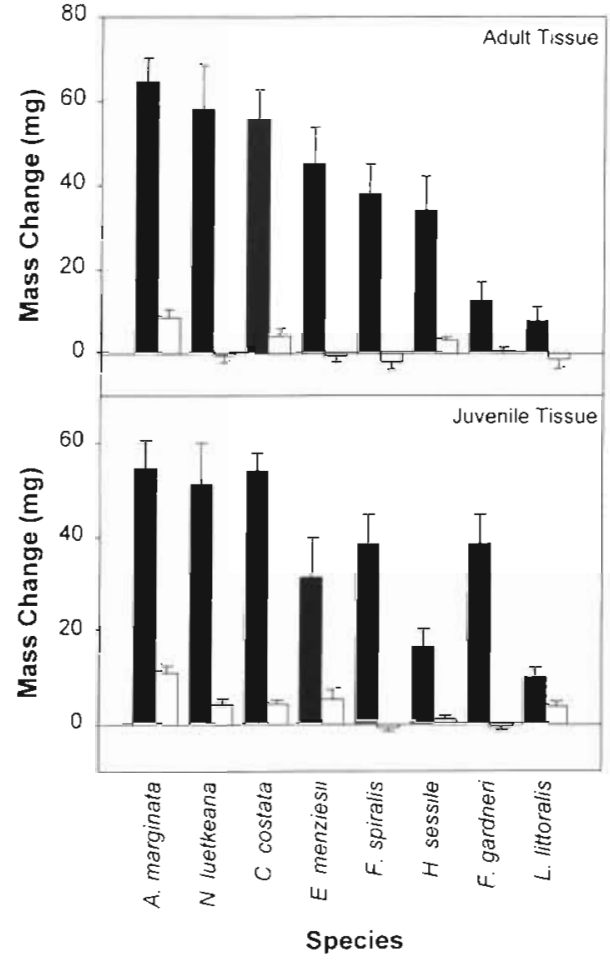

Fig. 4. Consumption rates of juvenile $(\mathrm{N}=7)$ and adult $(\mathrm{N}=7$ ) brown algal tissues by Idotea wosnesenskii. Symbols as in Fig. 1. Consumption rates of adult and juvenile tissues differed significantly among species (adults: $p=0.0003$ from Yao's $R$ test; juveniles: $p<0.001$ from Yao's $R$ test)

that may affect herbivore food preferences. Juveniles are generally smaller, thinner, and can be punctured more readily than adults (Van Alstyne et al. unpubl.). They can have higher tissue nitrogen concentrations and lower $\mathrm{C}: \mathrm{N}$ ratios (Van Alstyne et al. unpubl.) which may influence food choice because many herbivores are thought to be nitrogen limited (Mattson 1980). Concentrations of phlorotannins have been shown to decrease with increasing thallus length in Alaria marginata (Van Alstyne et al. unpubl.). However, in the northwest Atlantic, phlorotannin concentrations were lower in juveniles than adults of Fucus vesiculosus and $F$, evanescens, and similar in juveniles and adults of $F$. spiralis (Denton et al. 1990).

Food preferences for macroalgal species also differed markedly among the 4 herbivore species. Urchins and snails generally preferred adult kelps to adult fucoid brown algae; however, this was not the case for isopods. Differences in preferences may reflect differences in the feeding apparatuses, nutritional requirements, or tolerances to chemical defense levels of the herbivores. Of the 4 herbivore species used in this study, urchins have the largest mouthparts relative to the size of their food. Feeding rates of 

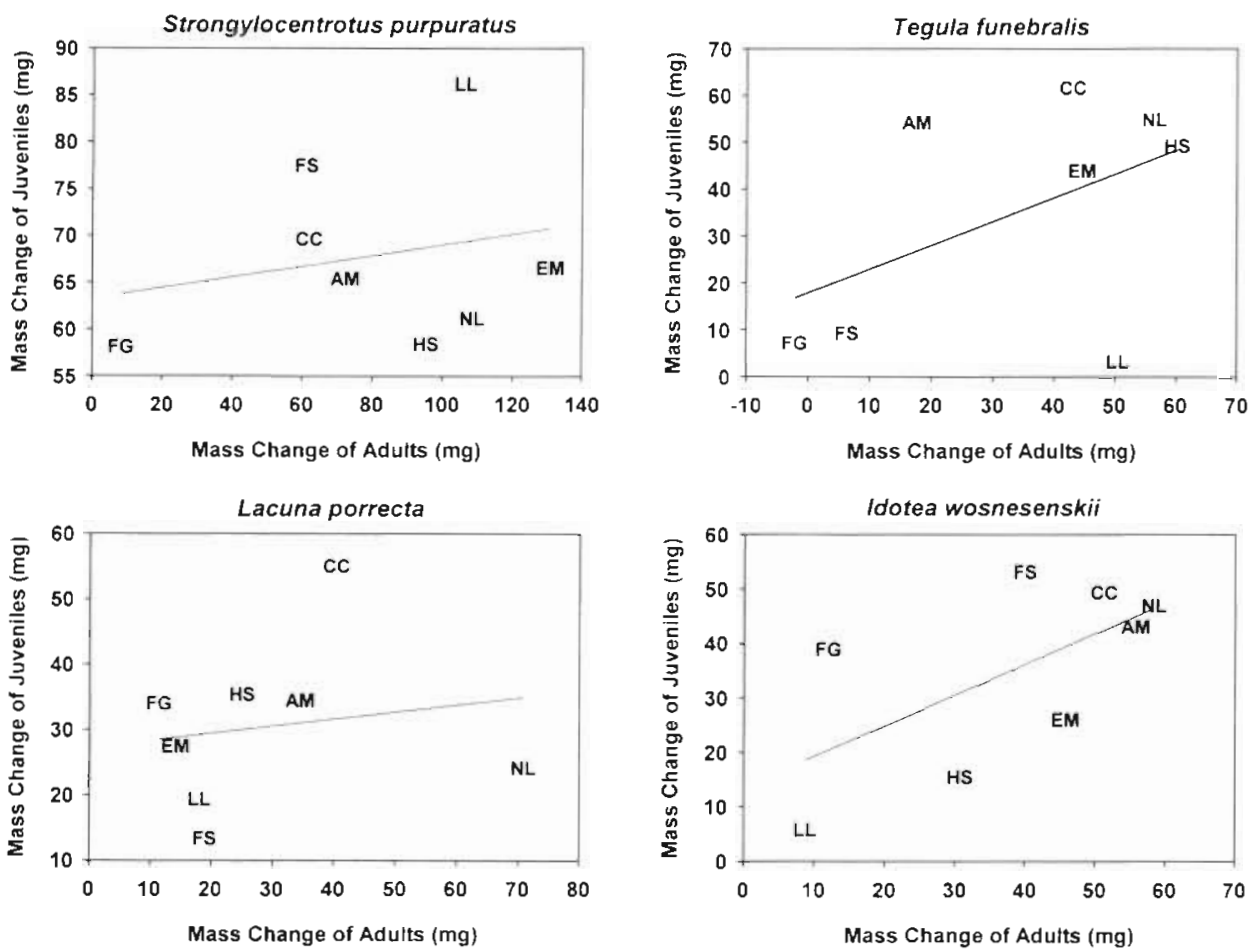

Fig. 5. Plots of consumption of adult versus juvenile tissues for each species (AM: Alaria marginata, CC: Costaria costata, EM: Egregia menziesii, FG: Fucus gardneri, FS: Fucus spiralis, HS: Hedophylum sessile, LL: Lessoniopsis littoralis, NL: Nereocystis luetkeana). Rates were calculated as the mean mass change in experimental arenas with grazers minus the mean mass change in the control arenas without grazers. Lines represent the best fit linear regression to the data. In all cases, there was no significant correlation between mass consumption of adult and juvenile tissues by herbivores (Pearson correlation coefficient, $p>0.05$ )

urchins and Tegula funebralis from the eastern Pacific region are known to be affected by concentrations of phlorotannins in their diets (Steinberg 1988, Steinberg et al. 1995), whereas mesograzers, small herbivores that often use algae as habitats as well as a food source, are often tolerant of chemical defenses (Hay et al. 1989a, b, 1990a,b). Small grazers such as Idotea and Lacuna porrecta may be less affected by the high concentrations of phenolic compounds in the fucoid brown algae and more responsive to differences in algal morphological features.

As pointed out by Gosselin (1997) in a study of ontogenetic changes in benthic intertidal snails, juveniles are not simply 'miniature adults' (Gibbs 1984). Our laboratory feeding experiments demonstrate that changes accompanying the development of seaweeds have the potential to affect interactions between species in the field.

Acknowledgements. We are grateful to J. Lubchenco and B. Menge for hosting K.L.V during her stay at Oregon State University and providing access to the Boiler Bay field site. K. Nielsen wrote the SAS program for conducting Yao's $R$ tests and provided helpful insights into the analysis of feedingpreference experiments. D. Padilla identified Lacuna porrecta. L. Weber of the Hatfield Marine Science Center gra- ciously allowed us to use his laboratory and HMSC facilities. Two anonymous reviewers made many helpful comments on the manuscript. This work was funded by an NSF grant. IBN 98-96012 to K.L.V.

\section{LITERATURE CITED}

Asano M, Kikuchi S, Kawamura T (1990) Effect of small herbivorous sea-snails on survival rates of the young laminariales plants. Bull Tohoku Natl Fish Res Inst 56:65-71

Bernard FR (1967) Studies on the biology of the naticid clam drill Polinices lewisi (Gould) [Gastropoda Prosobranchiata]. Fish Res Bd Can Tech Rep No. 42

Bird CJ, McLachlan J (1974) Cold hardiness of zygotes and embryos of Fucus (Phaeophyceae, Fucales). Phycologia 13:215-225

Brawley SH, Johnson LE (1991) Survival of fucoid embryos in the intertidal zone depends on developmental stage and microhabitat. J Phycol 27:179-186

Carpenter RC (1986) Partitioning herbivory and its effects on coral reef algal communities. Ecol Monogr 56:345-363

Cronin G, Hay ME (1996) Susceptibility to herbivores depends on recent history of both the plant and animal. Ecology 77:1531-1543

Dayton PK (1985) Ecology of kelp communities. Annu Rev Ecol Syst 16:215-245

Dean TA, Thies K, Lagos SL (1989) Survival of juvenile giant kelp: the effects of demographic factors, competitors, and grazers. Ecology 70:483-495 
Denton A, Chapman ARO, Markham J (1990) Size-specific concentrations of phlorotannins (anti-herbivore compounds) in three species of Fucus. Mar Ecol Prog Ser 65: $1.03-104$

Duggins DO (1980) Kelp beds and sea otters: an experimental approach. Ecology 61:447-453

Duggins DO, Dethier MN (1985) Experimental studies of herbivory and algal competition in a low intertidal habitat. Oecologia 67:183-191

Geiselman JA, McConnell OJ (1981) Polyphenols in brown algae Fucus vesiculosus and Ascophyllum nodosum: chemical defenses against the marine herbivorous snail, Littorina littorea. J Chem Ecol 7:1115-1133

Gibbs PE (1984) The population cycle of the bivalve Abra tenuis and its mode of reproduction. J. Mar Biol Assoc UK 64:791-800

Gosselin LA (1997) An ecological transition during juvenile life in a marine snail. Mar Ecol Prog Ser 157:185-194

Gosselin LA, Chia FS (1994) Feeding habits of newly hatched juveniles of an intertidal predatory gastropod, Nucella emarginata (Deshayes). J Exp Mar Biol Ecol 176:1-13

Gosselin LA, Chia FS (1995a) Characterizing temperate rocky shores from the perspective of an early juvenile snail: the main threats to survival of newly hatched Nucella emarginata. Mar Biol 122:625-635

Gosselin LA, Chia FS (1995b) Distribution and dispersal of early juvenile snails: effectiveness of intertidal microhabitat as refuges and food sources. Mar Ecol Prog Ser 128: $213-223$

Gosselin LA, Chia FS (1996) Prey selection by inexperienced predators: do newly hatched snails maximize energy gains on their first attack? J Exp Mar Biol Ecol $146: 265-282$

Gosselin LA, Quan PY (1997) Juvenile mortality in benthic marine invertebrates. Mar Ecol Prog Ser 146:265-282

Hawkins SJ, Hartnoll RG (1983) Grazing of intertidal algae by marine invertebrates. Oceanogr Mar Biol Ann Rev 21: $195-282$

Hay ME (1981) Herbivory, algal distribution, and the maintenance of between-habit diversity on a tropical fringing reef. Am Nat 188:520-540

Hay ME (1985) Spatial patterns of herbivore impact and their importance in maintaining algal species richness. Proc 5 th Int Coral Reefs Congr 4:29-34

Hay ME, Duffy JE, Fenical W (1989a) Host-plant specialization decreases predation on a marine amphipod: an herbivore in plants clothing. Ecology 71:733-743

Hay ME, Pawlik JR, Duffy JE, Fenical W (1989b) Seaweedherbivore-predator interactions: host-plant specialization reduces predation on small herbivores. Oecologia 75: $246-252$

Hay ME, Duffy JE, Pfister CA, Fenicall W (1990a) Chemical defense against different marine herbivores: are amphipods insect equivalents? Ecology 68:1567-1580

Hay ME, Duffy JE, Paul VJ, Renaud PE, Fenical W (1990b) Specialist herbivores reduce their susceptibility to predation by feeding on the chemically defended seaweed Avrainvillea longicaulis. Limnol Oceanogr 35:1734-1743

Hooker N, Morse DE (1985) Abalone: the emerging development of commercial cultivation in the United States. In: Huner JV, Brown EE (eds) Crustacean and mollusk cultivation in the United States. AVI Publishing, Westport, p 365-413

Keesing JK, Halford AR (1992) Field measurements of survival rates of juvenile Acanthaster planci: techniques and preliminary results. Mar Ecol Prog Ser 85:107-114

Lewis SM (1986) The role of herbivorous fishes in the organi- zation of a Caribbean reef community. Ecol Monogr 56 $183-200$

Lindquist N, Hay ME (1996) Palatability and chemical defense of marine invertebrate larvae. Ecol Monogr 66: $431-450$

Lubchenco J (1978) Plant species diversity in a marine intertidal community: importance of herbivore food preference and algal competitive abilities. Am Nat 112:23-39

Lubchenco J (1983) Littorina and Fucus: effects of herbivores, substrate heterogeneity, and pant escapes during succession. Ecology 64:1116-1123

Lubchenco J, Gaines SD (1981) A unified approach to marine plant-herbivore interactions. I. Populations and communities. Annu Rev Ecol Syst 12:405-437

Lubchenco J, Menge BA (1978) Community development and persistence in a low rocky intertidal zone. Ecol Monogr 48: $67-94$

Manly BJF (1993) Comments on the design and analysis of multiple-choice feeding-preference experiments. Oecologia 93:149-152

Mattson WJ (1980) Herbivory in relation to plant nitrogen content. Annu Rev Ecol Syst 11:119-161

Paine RI (1992) Food-web analysis through field measurement of interaction strength. Nature 355:73-75

Ragan MA, Glombitza K (1986) Phlorotannins, brown algal polyphenols. In: Round FE, Chapman DJ (eds) Progress in phycological research, Vol 4, Biopress Limited, Bristol, p $129-241$

Reed DC (1990) The effects of variable settlement and early competition on patterns of kelp recruitment. Ecology 71. $776-787$

Robles CD, Cubit JD (1981) Influence of biotic factors in an upper intertidal community: effects of grazing diptera larvae on algae. Ecology 62:1536-1547

Rowley RJ (1990) Newly settled sea urchins in a kelp bed and urchin barren ground: a comparison of growth and mortality. Mar Ecol Prog Ser 62:229-240

Schiel DR, Foster MS (1986) The structure of subtidal algal stands in temperate waters. Oceanogr Mar Biol 24:265-307

Steinberg PD (1984) Algal chemical defenses against herbivores: allocation of phenolic compounds in the kelp Alaria marginata. Science 223:405-407

Steinberg PD (1985) Feeding preferences of Tegula funebralis and chemical defenses of marine brown algae. Ecol Monogr 55:333-349

Steinberg PD (1988) The effects of quantitative and qualitative variation in phenolic compounds on feeding in three species of marine invertebrate herbivores. J Exp Mar Biol Ecol 120:221- 237

Steneck RS (1983) Escalating herbivory and resulting adaptive trends in calcareous algal crusts. Paleobiology 9 $44-61$

Steneck RS (1986) The ecology of coralline algal crusts: convergent patterns and adaptive strategies. Annu Rev Ecol Syst 17:273-303

Steneck RS (1988) Herbivory on coral reefs: a synthesis. Proc 6th Int Coral Reef Symp 1:37-49

Targett NM, Arnold TM (1998) Predicting the effects of brown algal phlorotannins on marine herbivores in tropical and temperate oceans. J Phycol 34:195-205

Vadas RL, Wright WA, Miller SL (1990) Recruitment of Ascophyllum nodosum: wave action as a source of mortality. Mar Ecol Prog Ser 61:263-272

Van Alstyne KL, Paul VJ (1990) The biogeography of polyphenolic compounds in marine macroalgae: temperate brown algal defenses deter feeding by tropical herbivorous fishes. Oecologia 84:158-163 
Werner EE, Gilliam JF (1984) The ontogenetic niche and species interactions in size-structured populations. Annu Rev Ecol Syst 15:393-425

Witman JD (1987) Subtidal coexistence: storms, grazing, mutualism, and the zonation of kelps and mussels. Ecol Monogr 57:167-187

Worm B, Chapman ARO (1998) Relative effects of elevated

Editorial responsibility: Charles Birkeland (Contributing Editor), Mangilao, Guam grazing pressure and competition from a red algal turf on two post-settlement stages of Fucus evanescens C. Ag. J Exp Mar Biol Ecol 220:247-268

Zann L, Brodie J, Berryman C, Naqasima M (1987) Recruitment, ecology, growth, and behaviour of juvenile Acanthaster planci (Echinodermata: Asteroidea). Bull Mar Sci 41:561-575

Submitted: September 6, 1998; Accepted: December 22, 1998 Proofs received from author(s): April 7, 1999 